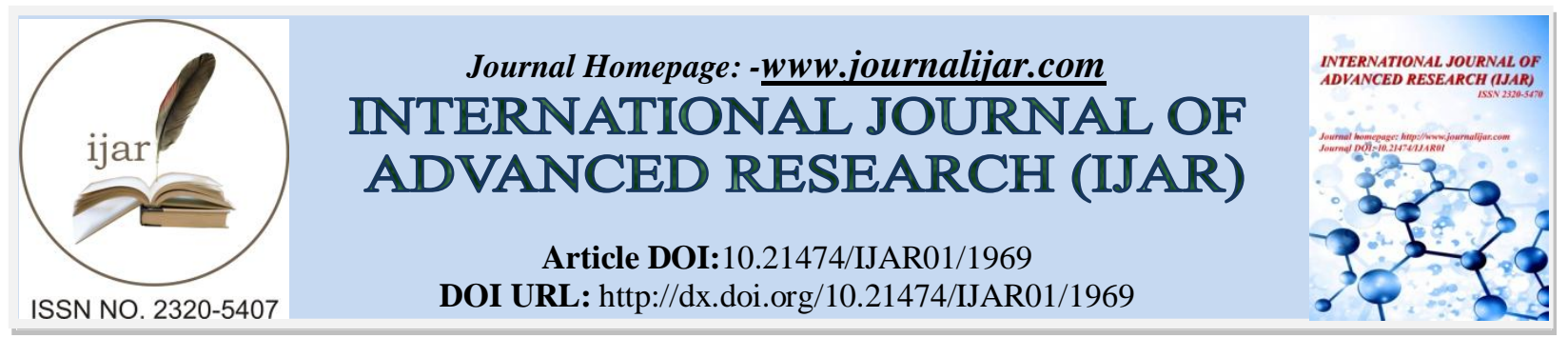

RESEARCH ARTICLE

\title{
MAPPING IDEAS: A COLLABORATION WITH INDUSTRY.
}

\author{
*Chynette Nealy. \\ University of Houston Downtown, College of Business, Department of Management, Marketing \& Business \\ Administration, 320 North Main, Suite B420, Houston, Texas 77002.
}

\section{Manuscript Info}

Manuscript History

Received: 26 August 2016

Final Accepted: 22 September 2016

Published: October 2016

Key words:-

business communication, career insight, concept mapping

\section{Abstract}

This article focuses on the challenge of helping learners to understand the realistic implications in business coursework. It begins with an overview about the reasoning used to examine adjusting a core course, business communication, required for all business majors. The next section reports findings from a pilot study that used concept maps via industry expectations to develop aBusiness Communication assignment focused on improving realistic understanding of business fields and writing deliverables.The final section discusses how connections between coursework and industry expectations helped business majors develop applicable discipline-based skills expected by industry.

Copy Right, IJAR, 2016,. All rights reserved.

\section{Introduction:-}

Within the context of bridging the gap between theory and practice, theoretically, there is general agreement among business faculty across business disciplines that a fundamental learner outcome should be to prepare business majors with skills expected by industry. Yet, business faculty operate with limited knowledge about learners in terms of academic preparedness and post academic performance in relation to industry expectations. The most common reason suggested by literature is that business faculty have limited opportunities to use industry feedback about how to develop skills (Moshiri\&Cardon, 2014; AACSB, 2011; Yu, 2010; Russ, 2009; Sapp \&Zang, 2009). This might help to understand the perceived practical gap regarding recent graduates in terms of industry expected outcomes, especially given employers expect new college graduates to contribute in "meaningful" and "innovative" ways once hired and that education institutions should be adjusting their programs to accommodate that need (Smith \& Clark, 2010, p. 41-57).

There are many challenges to addressing these employers' expectations; of particular interest to this author, a business professor, was literature that proposed adjusting programs to recognize that learners' knowledge and skill gaps derive from how little they know about expected workplace practices. These findings suggest learners are underpreparedwhen choosing to pursue a business degree(Moshiri\&Cardon, 2014; Capelli, 2012; Cardon\& Marshall, 2010; Hancock, et al., 2009). Within the scope of these findings, it is reasonable to infer these learners are also inadequately prepared given limited career insight. Career insight refers to the "degree to which individuals have realistic perceptions of themselves and their environment" (Feldman, 2003, p. 501). For instance, Hancock, et al. (2009) reported Accounting majors often do not recognize the importance of business communication and how it relates to their degree.Although the American Institute of Certified Public Accountants (AICPA) lists communication as a fundamental personal competency needed by all learners entering the accounting profession,

\section{Corresponding Author: Chynette Nealy}

Address:-University of Houston Downtown, College of Business, Department of Management, Marketing \& 1604 
regardless of the career path they choose (public/industry/government/ nonprofit) or the specific accounting services they will perform (AICPA, 2008). In a related manner, Finance majors appear to be challenged when required to write about financial concepts or to construct useful graphics (Carrithers\& Bean, 2008; Carrithers, et al. (2008).

While these findings are significant and contribute to related literature, academicians and industry representatives still grapple with the challenge of business majors' preparedness for the workplace.

Thus, a reasonablereview of course content and/or program adjustments might involve pedagogical strategies which include emphasis on reality-based content and deliverables. This rationale is supported by the accreditation organization, Association to Advance Collegiate Schools of Business (AACSB International). The organization encourages business programs to blur the boundaries between educational disciplines and offer innovative programs. A specific recommendation is for business programs to use effective pedagogies inclusive of active learning and technology (AACSB International, 2011; Biz Schools at Risk, 2002). Taken together these findings point to the importance of analyzing factors that might affect learners' levels of understanding content and skill development. Itisplausible here to suggest additional research opportunities to investigate factors, e.g. pre-major tracks or multidisciplinary approaches, that influence career insight related to learners' choice of major - business and nonbusiness.

Although this study focuses on business programs, a related approach, interdisciplinary coursework, might yield implications for mapping purposes about career insight. Interdisciplinary coursework stresses the connections among business fields, e.g. business communication, that might develop students into well rounded business professional with the interpersonal skills that they need in order or be successful (Athavale, et al., 2008). Reviewing from this perspective, academicians and industry representatives might be able to help learners develop realistic expectations before declaring business as a field of study.They might also be able to identify strategies to improve declared business majors' interests that facilitate engagement of continuous improvement of career insight and development. For this reason, the author examined the business communication course to identify usable data which might accommodate adjusting the course and/or business programs to address industry expectations.

The business communication course serves as a core courses for business majors across disciplines (e.g. accounting,finance,generalbusiness,insurance and risk management, international

business,management,management information systems, marketing,supply chain).Most business programs (undergraduate and graduate) require business communication, yet, the general industry perception suggests poor writing in the workplace is the result of "gaps" in developing writing skills in the classroom (Bessen, 2014; Belkins, 2014; Sharp \&Brumberger, 2013; Lentz, 2013;Nicolas \&Annous, 2013; Middleton, 2011; Jones, 2011; Kozel, 2010; Laster \& Russ, 2010; National Association of Colleges and Employers, 2010; Hynes \&Sigmar, 2009; National Commission on Writing, 2004).

\section{Method:-}

To investigate the issue, the author reviewed studies which surveyed business communication courses to map topics covered and types of assignments (Moshiri\&Cardon, 2014; Mitchell, et al., 2010; Russ, 2009;Du-Babcock, 2006). Next, a survey of job postings used by industries with professional connections to the author's university and college were examined. The goal was to collect data via a job analysis, process of systematic inquiry aimed at discovering and documenting the essential nature of work (Brannick et al., 2007). Findings showed various job postings from employers' descriptions of major functions and competencies required to perform them. Both sets of data were used to map business communication topics and assignments in two columns - academic and industry.

In order to pilot the data collected, forty invitations ranging across all business degrees e.g. accounting, finance, general business, insurance and risk management, international business, management, management information systems, marketing, supply chain) offered at the author's College of Business was sent to industry representatives, some of whom were graduates of one of the business programs. Twenty-five industry representatives, of which each business program was represented, agreed to participate in a round-table discussion about expected business communications skills. The purpose was to discuss the perception of a gap in terms of equipping business majors with industry expected business communication skills.

In preparing for the roundtable discussion, data collected was used to initiate discussions about business communications' topics covered and types of assignments. This allowed industry representatives to review the findings, specifically, the two column mapping process - topics covered and types of assignments to specific skills 
via job analysis. For example, a primary discussion point focused on the need for business majors to improve skills related to writing effective business messages, e.g. memorandumsand letters. The discussion examined in detail applying positive and other-oriented tones in business documents. All twenty-five industry representatives agreed there was a need for business majors to improve their understanding of the relevance of drafting a message with specific language (jargon) to the area of expertise (business major). This was a key finding in terms of the author's interest in the link between limited career insight of business majors and expected industry performance. Especially, given in planning the roundtable, the authordecided to use concept mapsto demonstrate a technique for assessing learners' connection and knowledge acquisition.

Concept Maps vary in many forms. For example, Concept Maps are referred to as Design Thinking in business management literature given the result-oriented approach to business development (Frisendal, 2012; Liedtka\& Ogilvie, 2011; Martin, 2009 \&2006; Brown, 2008). Generally, a concept map is a top-down diagram mapping the relationships among a set of connected concepts and ideas. It is a pictorial way to display how an individual, or group, perceives a concept, problem, or topic. A concept map is constructed, in most instances, from general ideas to more specific ideas. It is a deliberate and structured way of representing the relationship between disciplinary concepts and ideas. Concept maps, in particular are recognized as constructivist tools that facilitate active, reflective and meaningful learning (Bacabac, 2015; Davies 2011,Novak,2010, 2007, 1998; Hay, et al., 2008; Francis, 2006).This is useful for academic assessment purposes, especially, when the process uses the six levels of Bloom's Taxonomy (knowledge, comprehension, application, analysis, synthesis, evaluation) to guide learners' understanding of concepts and relationships between concepts when diagraming the Concept Map (Krathwohl, 2002; Anderson \&Krathwohl, 2001).

With this in mind, the author used this approach to demonstrate techniques for closing the gap between business programs and industry expectations. To help illustrate this point, a sample Concept Map follows. Industry representatives agreed the Concept Maps- Design Thinking- were helpful when reviewing, linking and cross-linking using information in the two columns (topics covered and types of assignments to specific skills via job analysis). Thus, meaningful dialogue occurred yielding realistic expectations with key takeaways. 

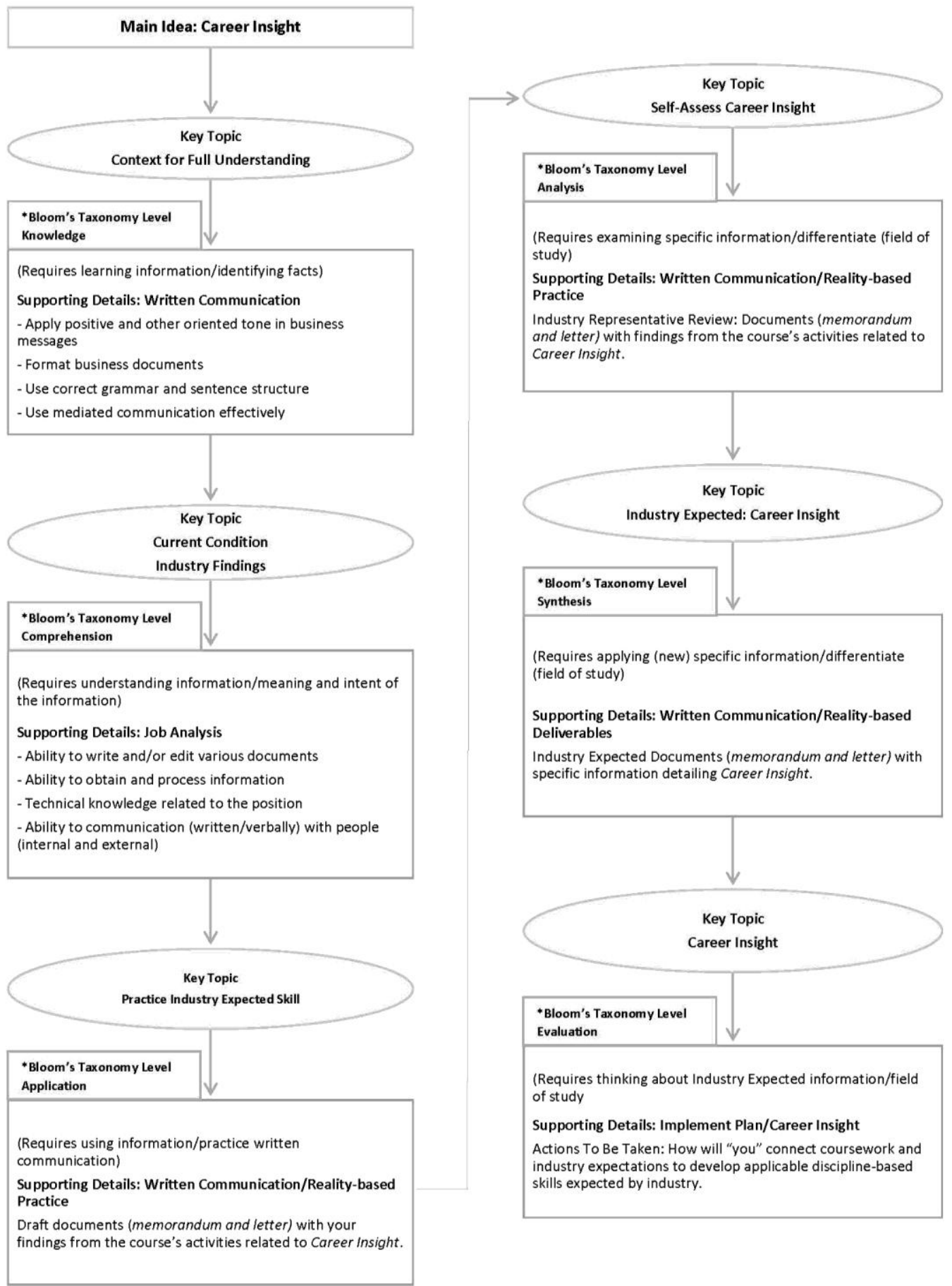

During discussion, a consistent theme became apparent: learners need to develop career insight about specific knowledge and skills within their majors. In reviewing the two columns' findings, industry representatives agreedlearners could improve their understanding of industry expected performance if they knew what to expect within their field of study before declaring their business major and/or introduction to course content related to business communication. The feedback from the industry representatives who interview and employ our business majors provided support for the author's interest in adjusting programs and/or course content focusing on developing learners' career insight given their limited understanding about expected workplace practices.

From this perspective, the author collaborated with industry representatives and designed applications useful for equipping learners with career insight. For planning purposes, information about the participants, preparation and an 
example of one of the assignments follow. The overall objective was to help learners develop career insight to improve their understanding of connecting theory and practice.

\section{Participants:-}

The sample population of this study was enrolled in a one semester core Business Communication class. There were 40 business majors:accounting (11), finance (8), general business (4), insurance and risk management (2), international business (5), management (2), management information systems (3), marketing (2) and supply chain (3).

Other demographics data (age, gender and work experience) were collected. Age ranging (21-58); Gender (26 women/14 men); and Work Experience (30 nontraditional learners working 40 hours or more aspiring career opportunities), 6 learners with internships within their field of study:(accounting, finance, international business) and 4 traditional learners without work experience.

\section{Preparation:-}

Learners (business majors offered in the College of Business) received two weeks (four class meetings) of course activities on career insight. These activities included: reading material, e.g. knowledge and skills (soft and hard) related to the learners' majorand discussions (panels with industry representativesand the college's career center). Learners were required to review two journals (academic/practitioner) and websites related to their major, e.g. other college business programs, companies, labor facts/government databases, etc.). These activities were designed for learners to focus on their major and collect preliminary data related to industry expectations in their field of study.

\section{Applications for Business Communication Learning Objectives}

To impress on learners the importance of developing a reality-based perspective about their declared field of study (Career Insight).

To help learners experience reality-based applications with specific skillslinked to their declared field of study.

Time to Complete

The first assignment, four class meetings, is needed for discussions and research time.

Career Insight Question: What written skills do employers request when they advertise position openings in your field?

Research Employment Posts: Research position openings in your field at an online job site. Examples include but are not limited to: posts on our job board in the College of Business/Career Center, Monster.com,US.jobs or LiveCareer. Identify five position openings in your fieldof study. Then prepare a list of the top three writing skills in your field of study. Use these findings to self-assess your knowledge in terms of qualifications for one of the positions within your field of study.

Class Meetings: Before class -read course content on writing effective business messages (memorandum and letter). Bring your findings (list of key elements) from the research applications to class. We will use examples from your findings and speakers from the panel discussionsto build "personalized" concept maps with key content related to each field of study enrolled in the class. Students (Business majors) should be able to show linkage to the discussionswhen writing effective business messages within the field of study. Next, we will examine basic model and sample model documents (memorandum and letter) within fields of study.These activities will help you focus on applying positive and other-oriented tones in business documents during the writing process.

Applications:(1) Draft a memorandum with your findings from the course's activities related to Career Insight. Make sure to explain and detail examples of the top three writing skills required in your field of study. Provide a citation list, APA format, at the bottom of the document.

(2) Draft a letter to your professor explaining how you plan to apply findings from the Career Insight application. Make sure to explain your plan for developing your writing skills within your field of studygiven industry expectations. 


\section{Discussion:- \\ Findings}

The timing of the course application was critical in helping business majors develop an understanding of industry expected skills within a field of study. Timing the application at the beginning of the semester allowed learners to form abstract base knowledge about specific skills within their field of study. By doing so, they were able to link and apply theoretical skills during the semester while developing practical business messages and documents related to their field of study. Hence, in terms of assessment, findings from the pilot study provided the author with mapping data that can be used to identify strategies for addressing closing the gap between learners' preparedness and industry's expected skills. Some key takeaways from the pilot study follow.

\section{Career Insight}

In general, four roadblocks stand between many students and career success: procrastination; rationalization; unrealistic expectations; and lack of understanding of how their academics, extracurricular activities, and work experience relate to their ability to complete successfully for a job that meets their professional and business needs (Clark, 2005, p.271).

Findings from the pilot study, mirrored related literature which suggest the need for early interventions that provide business majors with a "realistic set of expectations" for framing career insight. Helping business majors earlier in their courses to understand and develop industry expected skills improved their perception about workplace practices and career insight.Results from this pilot study suggested business communication faculty should consider using pedagogical strategies which include emphasis on reality-based content and deliverables.

\section{Concept Maps}

Of particular importance, similar to the industry representatives during the roundtable discussion, participants showed a preference to the use of Concept maps. The business majors were able to understand links between course topics and assignments to their specific field of study expectations. Since, the concept mapping process involved instructional sequence in each phase of the application, the author was able to assess via Bloom's Taxonomy levelsof understanding during the application, grading deliverables and the entire semester. Selected self-reported excerpts from participants are provided below about how this mapping process affected their career insight about writing skills within their field of study.

\section{Majors:-}

Accounting- As an Accounting major I placed more attention on how to develop quantitative skills(decisions and applications). After the first assignment on career insight, I shifted my focus to a more balanced approach between developing qualitative and quantitative skills. I discovered a large percentage of my daily activities in the workplace might involve writing about accounting procedures. The concept maps and model documents help guide my discovery of the importance of writing within my field.

General Business - The concept maps helped me to cross-link a broad range of skills listed for a person majoring in General Business. I discovered at the top of several skills listed by employers seeking to hire business graduates was writing business reports. The required documents, memo and letter, in the first assignment helped me to practice writing in my field of study. It also improved my understanding about career options.

While this study provided preliminary data, several important findings were revealed. A consistent theme mirroring related literature showed business communication skills, i.e. writing ability, ranked in the top percent in terms of importance for business majors to develop and/or possess. However, there was general disagreement among the ranking of other skills (soft/interpersonal qualities and hard/knowledge/technical expertise). A plausible explanation of this disagreement might be rooted in specific workplace trends such as: generational differences or functional aspects within each business major. The author plans to extend this study to collect additional data to examine identified workplace trends and specific skills. Examining the issue from this perceptive, the author propose to contribute to related literature by identifying strategies which might improve closing the gap between academic and industry expectations.

This pilot study provided a glimpse of how the business communication course might be adjusted to identify strategies for addressing academic preparedness in relation to industry expectations. It is important to note a 
limitation of the study in terms of the forty participants. However, a key takeaway was participants in the study were actively engaged in developing their career insight applicable to their fields of study. Given active engagement of learners, data useful for identifying gaps between theory and practice might be understood and applicable program and/or business communication course adjustments can be made to improve learners' outcomes mapped to industry performance.

\section{References:-}

1. AACSB International - The Association to Advance Collegiate Schools of Business. (2011).Recommendations to AACSB International from the globalization of management education task force. 3, Tampa, FLA. AACSB International.

2. American Institute of Certified Public Accountants (2008). AICPA Core Competency Framework for Entry into the Accounting Profession: The Framework. Retrieved fromhttp://www.aicpa.org/edu/corecomp.htm. New York: AICPA.

3. Anderson, L. \&Krathwohl, D. (2001). A taxonomy for learning, teaching, and assessing: a revision of Bloom's taxonomy of educational objectives. New York: Longman.

4. Athavale, M., Davis, R., \&Myring, M. (2008). The integrated business curriculum: An examination of perceptions and practices. Journal f Business Education, 83, 295-301.

5. Bacabac, F. (2015). Appropriating Intervention Through Concept Maps In Wring for Multimedia and the Web. Business and Professional Communication Quarterly, 78 (2), 115-135.

6. Belkin, D. (2015, January 16). "Test Finds College Graduates Lack Skills for White-Collar Jobs." The Wall Street Journal Online. Retrieved from http://www.wsj.com/articles/test-finds-many-students-ill-prepared-toenter-work-force-1421432744

7. Bessen, J. (2014). Employers aren't just whining - The "skill gap" is real. Harvard Business Review. Retrieved from https://hbr.org/2014/employers-arent-just-whinning-the skills-gap-is-real

8. Brannick, M., Levine, E. \&Morgeson, F. (2007). Job and Work Analysis: Methods, Research, and Applications for Human Resource Management. Edition 2, Sage Publications.

9. Bronson, E. (2007). Career and technical education is ideally suited to teaching students the soft skills needed to succeed in the 21st century workplace. Techniques: Connecting Education \& Careers, 82(7), 30-31.

10. Brown, T. (2008), Design Thinking. In Harvard Business Review (hbr.org), June 2008.

11. Capelli, P. (2012). Why good people can't get jobs: The skills gap and what companies can do about it. Philadelphia, PA: Wharton Digital Press.

12. Carrithers, D., \& Bean, J. (2008). Using a client memo to assess critical thinking of finance majors. Business Communication Quarterly, 71(1), 10-26.

13. Carrithers, D., Ling, T., \& Bean, J. (2008). Messy problems and lay audiences: Teaching critical thinking within the finance curriculum. Business Communication Quarterly, 71(2), 152-170.

14. Clark, T, (2005). The Business Profession: A Mandatory, Noncredit, Cocurricular Career Preparation Program for Undergraduate Business Majors. Business communication Quarterly, 68 (3), 271-289.

15. Davies, M. (2011). "Concept Mapping, Mind Mapping and Argument Mapping: What Are the Differences and Do They Matter?" Higher Education 62 (3): 279-301.

16. Du-Babcock, B. (2006). Teaching business communication: Past, present, and future. Journal of Business Communication, 43, 253-264.

17. Felder, R. \& Brent, R. (2000). Section E: How Do I Get Students Actively Involved in Learning? National Effective Teaching Institution. St. Louis, Missouri, 15-17.

18. Feldman, D. (2003). The antecedents and consequences of early career indecision among young adults. Human Resource Management Review, 13, 499-531.

19. Francis, R. (2006, Summer). Using Concept Maps as Assessment Tools: Defining Understanding. College Quarterly,9 (3), Seneca College of Applied Arts and Technology.

20. Frisendal, T. (2012), Design Thinking Business Analysis - Business Concept Mapping Applied, SpringerVerlag.

21. Hancock, P., Howieson, B., Kavanagh, M., Kent, J., Tempone, I., Segal, N. (2009) Accounting for the future: more than numbers. A collaborative investigation into the changing skillset for professional accounting graduates over the next ten years and strategies for embedding such skills into professional accounting programs. Australian Learning and Teaching Council [ALTC]: Strawberry Hills, NSW.

22. Hartman J. \&McCambridge, J. (2011). Optimizing Millennials' Communication Styles, Business Communication Quarterly, 74, 22-44. 
23. Hay, D., Kinchin, I. \&Lygo-Baker, S. (2008). "Making Learning Visible: the Role of Concept Mapping in Higher Education." Studies In Higher Education 33 (3): 295-311.

24. Hynes, G., \&Sigmar, L. (2009). The importance of business communication courses in employer hiring decisions. In S. Johnson (Ed.), First annual general business conference, conference proceedings (pp. 193-203). Huntsville, TX: Sam Houston State University. Retrieved fromwww.shsu.edu/ gba_www/gbaconference/documents/GeneralBusiness2009Proceedings.pdf

25. Jones, C. G. (2011). Written and computer-mediated accounting communication skills: An employer perspective. Business Communication Quarterly, 74, 247-271.

26. Kozel, B. (2010). Writing skills: A crisis as close as your inbox. Employment Relations Today, 36(4), 7-12.

27. Krathwohl , D. (2002). Revising Bloom's Taxonomy. Theory Into Practice,41 (4), 212-218.

28. Laster, N., \& Russ, T. L. (2010). Looking across the divide: Analyzing cross-disciplinary approaches for teaching business communication. Business Communication Quarterly, 73, 248-264.

29. Lentz, P.(2013).MBA Students' Workplace Writing: Implications for Business Writing Pedagogy and Workplace Practice, Business and Professional Communication Quarterly, 76 (4), 474-490.

30. Liedtka, J., Ogilvie T. (2011), Designing for Growth - A Design Thinking Toolkit for Managers. New York:Columbia University Press (Kindle edition).

31. Martin, R. (2009), The Design of Business - Why Design Thinking is the Next Competitive Advantage, Harvard Business Press (Kindle edition).

32. Martin, R. (2006), Design Thinking and How It Will Change Management Education: An Interview and Discussion. In Academy of Management Learning \& Education, 2006, Vol. 5, No. 4.

33. Middleton, D. (2011, March 3). Students struggle for words: Business schools put more emphasis on writing amid employer complaints. The Wall Street Journal. Retrieved from http://online.wsj.com/article/SB10001424052748703409904576174651780110970. html?mod=WSJ_Careers_CareerJournal_2\#articleTabs\%3Darticle

34. Mitchell, G., Skinner, L., \& White, B. (2010). Essential soft skills for success in thetwenty-first century workforce as perceived by business educators. Delta Pi Epsilon Journal, 52, 43-53.

35. Moshiri, F. \&Cardon, P. ( 2014). The State of Business Communication Classes: A National Survey, Business and Professional Communication Quarterly, 77, (3), 312-329.

36. National Association of Colleges and Employers. (2010, November). Job Outlook 2011. Retrieved from http://career.pages.tcnj.edu/files/2011/07/Job_Outlook_2011_Full_Report_PDF1.pdf

37. National Center for Education Statistics (2012). The Nation's Report Card: Writing 2011 (NCES 2012-470). Institute of Education Sciences, U.S. Department of Education, Washington, D.C.

38. National Commission on Writing. (2004). Writing: A ticket to work . . . or a ticket out? A survey of business leaders. Retrieved from http://www.collegeboard.com/prod_downloads/writingcom/writing-ticket-to-work.pdf

39. Nicolas, M. O., \&Annous, S. (2013). Assessing WAC elements in business syllabi. Business Communication Quarterly, 76, 172-187.

40. Novak, J. (2010), Learning, Creating, and Using Knowledge: Concept Maps as Facilitative Tools in Schools and Corporations. Routledge.

41. Novak, J. (2007). The theory underlying concept maps and how to construct them. Retrieved from http://cmap.ihmc.us/Publications/ResearchPapers/TheoryUnderlyingConceptMaps.pdf.

42. Novak, J. (1998). Learning, creating, and using knowledge: Concept maps as facilitative tools in schools and corporations. Mahwah, NJ: Lawrence Erlbaum Associates.

43. Robles, M. (2012). Executive Perceptions of the Top 10 Soft Skills Needed in Today's Workplace. Business Communication Quarterly, 75(4) 453-465.

44. Russ, T. (2009). The Status of the Business Communication Course at U.S. Colleges and Universities. Business Communication Quarterly, 72 (4), 395-413.

45. Sharp, M. \&Brumberger, E. (2013). Business communication curricula today: Revisiting the top 50 undergraduate business schools. Business Communication Quarterly, 76, 5-27.

46. Society for Human Resource Management. (2016). What is a competency? Retrieved from https://www.shrm.org/hrcompetencies/pages/faqs.aspx\#01

47. Yu, H. (2010). Bring workplace assessment into business communication classrooms: A proposal to better prepare student for professional workplaces. Business Communication Quarterly, 73, (1), 21-3. 